\title{
Factors Influencing Alumni Donations
}

\author{
Sarunya Lertputtarak ${ }^{1} \&$ Surat Supitchayangkool ${ }^{1}$ \\ ${ }^{1}$ Grduate School of Commerce, Burapha University, Thailand \\ Correspondence: Sarunya Lertputtarak, Surat Supitchayangkool, Grduate School of Commerce, Burapha \\ University, 169 Longhard Bangsaen Road, A. Muang, Chonburi, 20131, Thailand. E-mail: \\ sarunya_L@hotmail.com
}

Received: January 12, 2014

Accepted: January 28, $2014 \quad$ Online Published: February 21, 2014

doi:10.5539/ijbm.v9n3p170

URL: http://dx.doi.org/10.5539/ijbm.v9n3p170

\begin{abstract}
The main purposes of this study were to study demographic factors, academic system, and social networks and other communication tools which can influence alumni donations. Using quantitative research involving questionnaires, the participants of this study were former and current students of master and doctoral degree programs in business from one of the government universities in Thailand. The results showed that academic system, social networks and other communication tools have an influence on a willingness to donate. Whereas the alumni and current students' gender, age, marital status have no relationship with a willingness to donate. Student satisfactory interactions have no influence on a willingness to donate either.
\end{abstract}

Keywords: Alumni, donation, Thailand

\section{Introduction}

Higher education fund raising is essential for the survival of institutions as institution tuition fees and support funds from the government can no longer be the sole financial supports for an institution. In order for universities to keep up with rising costs, additional resources must be acquired to keep programs running and develop curricula.

The alumni relationship is essential to an institution's advancement because the alumni are the most loyal support group of an institution. The more alumni are embedded with the institution, then the more relevant as a component they become within its networks and relationships (Chi, Jones, \& Grandham, 2012). Alumni can perform many roles for institutions such as volunteering their time on committees, participating at campus events or providing financial help.

Nevertheless, it is not an easy task to motivate the alumni to donate their time and money. Generally, not much is known about alumni opinions, beliefs, and preferences at universities. A huge number of alumni are non-donor, in that they do not make contributions to their colleges or universities (Kaplan, 2007). Previous studies attempted to find and understand the motivational factors of those individuals who are more likely to contribute to the college or university from which they graduated as well as their motives for giving, especially those alumni who have the financial resources to become major donors. However, the results of previous studies cannot give definite answers as to what the institutions should do to motivate the alumni to participate in university donation programs or events.

Hence, researching about alumni financial support is very beneficial. This research aimed to study factors which influence alumni to donate in order to understand unique alumni perspectives for encouraging them to make charitable contributions (Schervish, 2005; Van Slyke \& Brooks, 2005). Guided by the results of this study, institutions will be able to organize their development resources more appropriately. Leaders of alumni relations programs and management teams could utilize the results of this research for more effective communication with alumni about an institution. Efforts should be taken to ensure that alumni are connected to their university to enhance their loyalty. 


\section{Literature Review}

\subsection{Factors that Motivate Donating}

\subsubsection{Personal Data: Gender, Age, Marital Status, and Year of Graduation}

Gender as a predictor has yielded mixed results. Harris-Vasser (2004) concluded that men give more than women. While Mesch (cited in Baruch \& Sang, 2012, p.811) got opposite results as women gave more than men. MBA females reported less benefit than men in terms of pay and career progression according to Simpson \& Ituma (2009). Lara \& Johnson (2008 as cited in Baruch \& Sang, 2012, p. 811) found a direct positive relationship between age and giving. Older alumni are more likely to donate than younger alumni. Thomas (2005) observed a minor but significant relationship between having an alumni spouse and the amount the couple give, but not whether or not they give.

Caboni \& Eiseman (2003), Dean (2007), and Sun (2005) have observed a positive correlation between years since graduating and giving where alumni who graduated more recently were less likely to contribute than those alumni with a longer time span since graduating.

\subsubsection{Academic System: Quality of an Institution's Faculty and Satisfactory Interactions with Faculty and Staff}

Dean (2007) concluded that educational experiences had a positive impact on alumni participation in alumni programming and alumni donating and that alumni participation positively related to alumni donating.

The study by Terry and Macy (2007) found that graduates preferred to donate to an institution which they already viewed as being successful. Alumni donations were positively predicted by the selectivity and prestige of institutions.

Several researchers have concluded that graduates who were satisfied with their college experience are more likely to contribute to the college or university according to Sun, Hoffman \& Grady (2007). McAdoo (2010) studied the impact of student experiences on future alumni involvement at the University of Central Florida. Utilizing secondary data from the same alumni survey instrument as this study (the Alumni Attitude Study) the findings indicated that there was a relationship between involvement as a student and reported satisfaction with the college experience. Supported by the study of Baruch and Sang (2012), alumni involvement would predict donation behavior that was accounted for by each of the predictor variables such as; MBA satisfaction, university prestige, and current salary.

"Satisfactory interactions with faculty and staff are critical to students' positive academic experience" (GMAC, 2006, cited in Baruch \& Sang, 2012, p. 811). Gaier (2005) found that the variables related to academic work (for example the coursework in a major course) had the strongest relationship to future philanthropy, and the variables associated with academic interactions and interpersonal relationships (for example relationships with faculty and staff) were more closely connected to non-financial support.

Pascarella and Terenzini (2005) examined career-related variables, such as career-relevant skills, career choice, occupational status, and explored the net impact of various types of student interaction with a faculty based on the dimensions of career development and career attainment. Their findings indicated that the quality of an institution's faculty not only impacts on students' and alumni identification with an institution, but also influences students' careers after graduation.

\subsubsection{Social Networks and Other Communication Tools Used by an Institution with Alumni and Current Students}

Effective communication with alumni is an important determinant of giving, and the alumni systems should be developed in the ways that increase the interaction among current students and alumni and between alumni and a faculty according to Chi, Jones, \& Grandham (2012). Alumni magazines, e-newsletters and mass e-mails are a few of the many tools used to communicate with alumni, and alumni associations must stay ahead of the technology curve to most successfully reach graduates of every decade. Hoyt (2004) analyzed survey responses from 193 alumni at a public college and suggested that "the alumni office should send a mailing at least every six months to all degreed alumni to maintain current contact information" (p. 20). Visiting an alumni website also influenced alumni to donate according to Dean (2007). 


\subsection{Conceptual Framework}

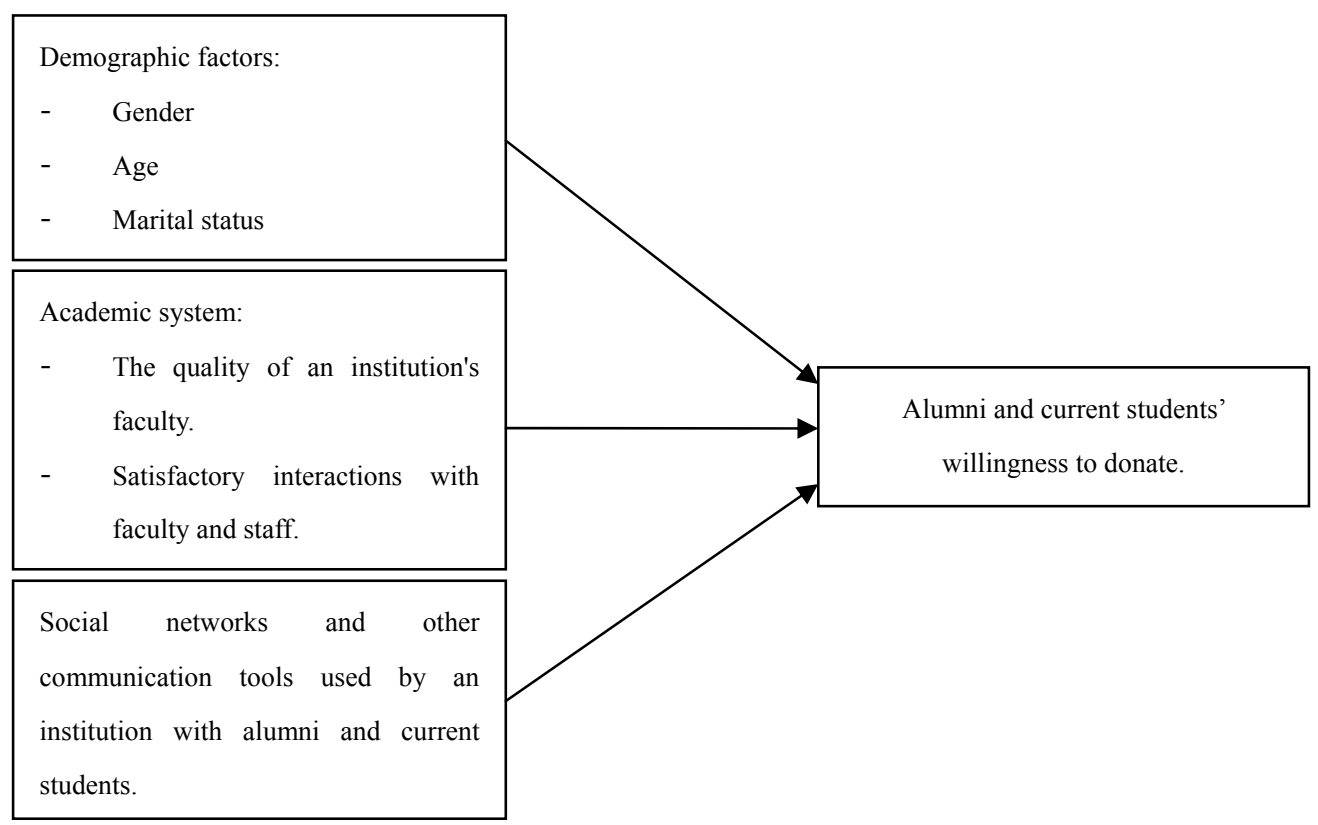

Figure 1. Conceptual framework of this study social networks and other communication tools

\section{Methodology}

The sample in this study was the alumni and current students of the master and doctoral degree business programs in one of the government universities in Thailand. The post-graduate students in Business Administration Management (MBA and DBA) programs were a potential source of income for universities, particularly given that they were more likely to donate than graduates of other programs according to Baruch \& Sang (2012). The respondents were selected by convenience sampling from a list of alumni. There were 800 questionnaires distributed to respondents by personal contact, e-mails and follow up telephone calls. There were 456 returned questionnaires which were a response rate of fifty seven per cent.

The questionnaires contained 4 sections: Section 1 contained the respondents' personal information. The questions were in the form of a check-list using both nominal and ordinal scales. Respondents could choose only one answer. Section 2 was about the academic system including the quality of the institution's faculty and satisfaction with the institution experience. Section 3 was about social networks and other communication tools used by an institution with alumni.

The questionnaire sections 2 and 3 were in the form of a Likert scale ranging from: $1=$ very low, $2=$ low, $3=$ moderate, $4=$ high, and $5=$ very high.

Section 4 contained a question about alumni and current students on their willingness to donate. The question was in the form of a check-list using both nominal scales such as willing to donate and not donate.

Reliability: The internal consistency of the indicators representing each construct was evaluated using Cronbach Alpha with the minimum threshold of 0.70 being deemed acceptable (Nunnally, 1978). The Cronbach alpha for the academic system was 0.952 and for the social networks and other communication tools it was 0.964 . The hypotheses were tested by Logistic Regression and Pearson chi-square.

\section{Results}

\subsection{Respondents' Demographic Factors}

There were 456 respondents of which 264 were female (57.90\%) and 192 male (42.10\%). The age of 194 respondents $(42.50 \%)$ was less than 30 years old and 306 of the respondents $(67.10 \%)$ were single.

Respondents who had a willingness to donate was 398 people $(87.30 \%)$, with those not donating being 58 people (12.70\%). The results of the respondents' personal information are demonstrated in Table 1. 
Table 1. Respondents' personal information

\begin{tabular}{llll}
\hline Respondents' personal information & & Frequency & Percentage \\
\hline \multirow{2}{*}{ Gender } & Male & 192 & 42.10 \\
& Female & 264 & 57.90 \\
\hline \multirow{3}{*}{ Age } & Less than 30 years old & 194 & 42.50 \\
& $31-40$ years old & 190 & 41.70 \\
& $41-50$ years old & 66 & 14.50 \\
\hline \multirow{3}{*}{ Marital status } & More than 50 years old & 6 & 67.10 \\
& Single & 306 & 32.00 \\
\hline \multirow{2}{*}{ Donation intention } & Married & 146 & 0.90 \\
\hline
\end{tabular}

\subsection{Descriptive Analysis of Variables}

For the academic system: The level of the quality of an institution's faculty was at a high level $(M=3.77)$.

Sequencing was by mean ranging from a maximum to a minimum such as; knowledge/skill /training for career, admissions process, variety of course offerings, orientation for new students, and quality of instruction in a course.

The level of satisfactory interactions with faculty and staff was at a high level too $(M=3.85)$. Sequencing was by mean ranging from maximum to minimum such as; satisfaction with friends in other classes, satisfaction with friends in your class, satisfaction with staff, and satisfaction with lecturers.

The level of social networks which influence donation was at a high level $(M=3.52)$. Sequencing was by mean ranging from maximum to minimum such as; facebook or other social network, web-based or emailed updates, invitation to join institution activities, electronic alumni directory, and an alumni magazine.

The results of the descriptive analysis of variables are demonstrated in Table 2.

Table 2. Descriptive analysis of variables

\begin{tabular}{|c|c|c|c|c|}
\hline & & $\mathbf{M}$ & SD & Level \\
\hline \multirow[t]{11}{*}{ Academic system } & The quality of an institution's faculty & 3.77 & 0.54 & High \\
\hline & 1. Admissions process & 3.82 & 0.63 & High \\
\hline & 2. Orientation for new students & 3.73 & 0.75 & High \\
\hline & 3. Variety of courses being offered & 3.81 & 0.49 & High \\
\hline & 4. Quality of instruction in a course & 3.55 & 0.81 & High \\
\hline & 5. Knowledge/skill /training for career & 3.94 & 0.06 & High \\
\hline & Satisfactory interactions with faculty and staff & 3.85 & 0.79 & High \\
\hline & 6. Satisfaction with staff & 3.66 & 0.88 & High \\
\hline & 7. Satisfaction with lecturers & 3.59 & 0.88 & High \\
\hline & 8. Satisfaction with friends in your class & 3.94 & 0.69 & High \\
\hline & 9. Satisfaction with friends in other classes & 4.23 & 0.71 & High \\
\hline \multirow{6}{*}{$\begin{array}{l}\text { Social networks and } \\
\text { other communication } \\
\text { tools }\end{array}$} & Social networks and other communication tools & 3.52 & 0.68 & High \\
\hline & 10. Facebook or other social network & 3.75 & 0.90 & High \\
\hline & 11. Web-based or emailed updates & 3.69 & 0.92 & High \\
\hline & 12. Alumni magazine & 3.05 & 0.95 & Moderate \\
\hline & 13. Electronic alumni directory & 3.53 & 0.90 & High \\
\hline & 14. Invitation to join institution activities & 3.59 & 0.83 & High \\
\hline
\end{tabular}




\subsection{Results of Hypothesis Testing}

The hypotheses were tested by Logistic Regression using SPSS software provided by the Graduate School of Commerce, Burapha University. The results were as follows.

Hypothesis 1: alumni and current students' demographic factors have a relationship with their willingness to donate.

By testing the hypothesis, the results showed that alumni and current students' gender, age, and marital status had no relationship with their willingness to donate.

Table 3. The relationship between alumni and current students' demographic factors and their willingness to donate

\begin{tabular}{|c|c|c|c|c|c|}
\hline \multirow[t]{2}{*}{ Gender } & \multicolumn{2}{|c|}{ Willing to donate } & \multirow[t]{2}{*}{ Total } & \multirow[t]{2}{*}{$\chi^{2}$} & \multirow[t]{2}{*}{ P-value } \\
\hline & Yes & No & & & \\
\hline Male & 172 & 20 & 192 & 1.58 & 0.208 \\
\hline Female & 226 & 38 & 264 & & \\
\hline Total & 398 & 58 & 456 & & \\
\hline \multicolumn{6}{|l|}{ Age } \\
\hline Less than 30 years old & 168 & 26 & 194 & 1.53 & 0.675 \\
\hline 30-40 years old & 168 & 22 & 190 & & \\
\hline $41-50$ years old & 56 & 10 & 66 & & \\
\hline More than 50 years old & 6 & 0 & 6 & & \\
\hline Total & 398 & 58 & 456 & & \\
\hline \multicolumn{6}{|l|}{ Marital status } \\
\hline Single & 264 & 42 & 306 & 1.27 & 0.530 \\
\hline Married & 130 & 16 & 146 & & \\
\hline Divorce & 4 & 0 & 4 & & \\
\hline Total & 398 & 58 & 456 & & \\
\hline
\end{tabular}

Hypothesis 2: Academic system can influence their willingness to donate.

Hypothesis 2.1: The quality of an institution's faculty can influence alumni and current students' willingness to donate.

Table 4. The influence of the quality of an institution's faculty on alumni and current students' willingness to donate

\begin{tabular}{lcccc}
\hline The quality of an institution's faculty & B & SE & Wald & P-value \\
\hline 1. Admissions process & 0.480 & 0.239 & $4.030^{*}$ & 0.045 \\
2. Orientation for new students & 0.493 & 0.213 & $5.377^{*}$ & 0.020 \\
3. Variety of course offerings & 0.861 & 0.299 & $8.312^{* *}$ & 0.004 \\
4. Quality of instruction in course & 0.292 & 0.211 & $1.911^{*}$ & 0.047 \\
5. Knowledge/skill /training for career & 0.010 & 0.259 & 0.001 & 0.970 \\
Constant & 5.678 & 1.159 & $23.989^{* *}$ & 0.000 \\
\hline
\end{tabular}

Pseudo $\mathrm{R}^{2}=0.218 ; * \mathrm{P}$-value $<0.05 ; * *$ P-value $<0.01$.

Solving the hypothesis: the results showed that the quality of an institution's faculty can have an influence on a willingness to donate.

Willingness to donate $=5.678+0.480$ (Admissions process) ${ }^{*}+0.493$ (Orientation for new study) ${ }^{*}+$ 0.861 (Variety of course offerings) ${ }^{* *}+0.292$ (Quality of instruction in course) ${ }^{*}+0.010$ (Knowledge/skill /training for career) $+\mathrm{e}$

Hypothesis 2.2: The satisfaction of alumni and current students toward process can influence their willingness to donate. 
Table 5. The influence of satisfaction of alumni and current students on their willingness to donate

\begin{tabular}{lcccc}
\hline The satisfaction of alumni and current students & B & SE & Wald & P-value \\
\hline 1. Satisfaction with staff & 0.178 & 0.202 & 0.775 & 0.379 \\
2. Satisfaction with lecturers & 0.030 & 0.092 & 0.104 & 0.747 \\
3. Satisfaction with friends in your class & 0.263 & 0.202 & 1.701 & 0.192 \\
4. Satisfaction with friends in other classes & 0.304 & 0.204 & 2.218 & 0.137 \\
Constant & 0.448 & 0.878 & 0.260 & 0.610 \\
\hline
\end{tabular}

Pseudo $\mathrm{R}^{2}=.066$.

Solving the hypothesis; the results showed that the satisfaction of alumni and current students toward process cannot influence a willingness to donate.

Willingness to donate $=.447+0.178$ (Satisfaction with staff) +0.030 (Satisfaction with lecture) + 0.263 (Satisfaction with friends in your class) +0.304 (Satisfaction with friends in other classes) $+\mathrm{e}$

Hypothesis 3: Social networks and other communication tools can influence alumni and current students' willingness to donate.

Table 6. The influence of social networks and other communication tools on alumni and current students' willingness to donate

\begin{tabular}{lllll}
\hline Social networks and other communication tools & $\mathrm{B}$ & $\mathrm{SE}$ & Wald & P-value \\
\hline Facebook & 0.303 & 0.195 & $2.403 *$ & 0.021 \\
Web-based or emailed updates & 0.159 & 0.193 & $0.677 * *$ & 0.010 \\
Alumni magazine & 0.519 & 0.217 & $5.747 *$ & 0.017 \\
Electronic alumni directory & 0.158 & 0.228 & 0.483 & 0.487 \\
Invitation letters to join institution activities & 0.534 & 0.241 & $4.917 *$ & 0.027 \\
Constant & 2.424 & 0.779 & $9.688^{* *}$ & 0.002 \\
\hline Pseudo $\mathrm{R}^{2}=0.156 * *$ P-value $<0.05 * * *$ P-value $<0.01$ & & & &
\end{tabular}

Pseudo $\mathrm{R}^{2}=0.156 ; *$ P-value $<0.05 ; * *$ P-value $<0.01$.

The results showed that social networks and other communication tools can influence alumni and current students' willingness to donate.

Willingness to donate $=2.424+0.303$ (Facebook) $*+0.159$ (Web-based or emailed updates) ${ }^{* *}+0.519$ (Alumni magazine)* +0.158 (Electronic alumni directory) +0.534 (Invitation letters to join institution activities)* $+\mathrm{e}$.

\section{Discussion}

The results were that the alumni and current students' gender, age, and marital status had no relationship with a willingness to donate. This can be explained in that the majority of the respondents' (336) were less than 41 years old and that they had not yet reached an age to have the disposable income necessary to make donations. These were the same results as the study by Baruch and Sang (2012) where neither gender nor age was significantly related to financial donations.

The academic system had an influence on a willingness to donate. The quality of an institutions' faculty can predict alummi donation. A variety of courses being offered provided more opportunities for institutions to gain more students and so increase the possibility to have more donations. A convenient administration process and orientation ceremony for new students also became an important component because it could make students be more impressed and feel more satisfied. Furthermore, the quality of instruction in courses can predict an alumni's willingness to donate. The results of this study were supported by the research of Gaier (2005) and Dean (2007) who found that variables which have a significant positive relationship with alumni donating were core education requirements such as; coursework in a student's major course, the quality of a faculty, the amount of contact with a faculty, the commitment of the faculty to teaching, the quality of instruction in major courses, the availability of required courses, the variety of course offerings, the relationship with faculty and staff, and the overall academic experience. Sun, Hoffman and Grady (2007) also advised that alumni fundraisers should be involved in the conversation regarding how best to enhance student extracurricular activities, career council, and academic improvements. The stronger an individual's identification with the organization is then the more likely he or she is to provide support. 
Satisfactory interactions had no influence on a willingness to donate as Hawawini (2005) and Baruch and Sang (2012) discussed that after graduation there is little contact between the business schools and graduates. Therefore, business schools should plan to consider about how to enhance a continued relationship after students have graduated. Gaier (2005) and Dean (2007) found that the variables associated with academic interactions and interpersonal relationships (for example the relationships with faculty and staff) were connected to non-financial support.

Social networks and other communication tools had an influence on a willingness to donate, especially invitation letters to join institution activities, an alumni magazine, facebook and web-based sites or email updates. The simple methods of magazines and letters still influence the alumni to donate, while social networks are widely used as a tool for communication these days. In addition, social networking is a powerful tool for people to meet and interact. It is time to design and use a social network-style alumni system according to Chi, Jones, \& Grandham (2012). The ability of an institution to effectively communicate, hence, successfully connect to the alumni and students was critical in establishing a platform upon which greater levels of alumni donations can become possible. Sun, Hoffman and Grady (2007) analyzed alumni survey responses from a Midwestern public university and concluded that engaged alumni were more likely to understand the needs of the university than those not engaged. The researchers also discovered that reading alumni publications was a significant predictor of whether a graduate was a donor or not.

\section{Conclusions and Recommendations}

\subsection{Conclusions}

It is crucial for educational institutions to generate strong connections with alumni and current students in order to enhance the chance for further donations in the future. The academic system had an influence on a willingness to donate. The quality of an institutions' faculty such as; a variety of courses being offered, a convenient administration process as well as an orientation ceremony for new students, and the quality of instruction in courses also became important components which can predict an alumni's willingness to donate. Social networks and other communication tools had an influence on a willingness to donate, especially invitation letters to join institution activities, an alumni magazine, facebook and web-based sites or email updates.

\subsection{Recommendations}

1) Institutions should place emphasis on the quality of an institutions' faculty by providing a variety of courses to be offered, a convenient administration process as well as an orientation ceremony for new students, and a quality of instruction in courses. Examining the demand and market situations before creating suitable programs for students can increase the chance to gain more students and who will become alumni. Successful programs can assist students to become successful in their careers and then they will have more income.

2) As there have been big changes in recent years, the development of the internet and social networking forces the alumni communication system to undergo huge changes. Hence, it is really necessary for institutions to focus on the alumni networks and find ways to enhance their growth and development. Regular and innovative tools can be used to connect with alumni especially invitation letters to join institution activities, an alumni magazine, facebook and web-based sites or email updates.

\subsection{Recommendations for Further Study}

6.3.1 Many key variables are outside the control of a faculty such as a national or global economic situation. However, there are many variables within a faculty which can be influenced such as; a student support service, volunteer programs, and donor opportunities which can be studied in depth. The in-depth examination can increase information that would help a faculty develop or redesign its alumni engagement programs and effectively allocate resources.

6.3.2 This study was conducted at one of the universities in Thailand which had its own unique culture. The scope of this study would need to be broadened to see if similar results would be found at other universities in other countries. The repeat study would increase the level of confidence with findings and allow the research to validate the data collected.

\section{Limitations}

As this study only collected data at the Graduate School of Commerce in Burapha University then the results may be limited for the unit of study. However, it could be applied at an institution having the same characteristics such as institutions which teach post-graduate programs. 
This study is limited by using retrospective data and having participants recall and interpret past events. Collecting data from alumni years after they have graduated involves the risk of collecting distorted results because their attitudes may change over time.

\section{References}

Baruch, Y., \& Sang, K. J. C. (2012). Predicting MBA graduates' donation behavior to their alma mater. Journal of Management Development, 31(8), 808-825. http://dx.doi.org/10.1108/02621711211253268

Caboni, T. C., \& Eiseman, J. (2003, October). Organizational identification and the voluntary support of higher education. Paper presented at the Association for the Study of Higher Education annual meeting.

Chi, H., Jones, E. D., \& Grandham, L. P. (2012). Enhancing mentoring between alumni and students via Smart Alumni System. Procedia Computer Science, 9, 1390-1399. http://dx.doi.org/10.1016/j.procs.2012.04.153

Dean, M. S. (2007). Perceptions of chief development officers about factors that influence alumni major giving. Unpublished doctoral dissertation, Southern Illinois University, Carbondale.

Gaier, S. E. (2005). Alumni satisfaction with their undergraduate academic experience and the impact on alumni giving and participation. International Journal of Education Advancement, 5(4), 279-288. http://dx.doi.org/10.1057/palgrave.ijea.2140220

GMAC. (2006). MBA alumni perspective survey comprehensive data report. Retrieved from $\mathrm{http} / / / \mathrm{www} . g m a c . c o m / c o m m u n i t y /$ media/p/243.aspx

Harris-Vasser, D. G. (2004). A comparative analysis of the aspects of alumni giving at public and private historically Black colleges and universities. Unpublished doctoral dissertation, Tennessee State University, Nashville.

Hawawini, G. (2005). The future of business schools. Journal of Management Development, 24(9), 770-782. $\mathrm{http}: / / \mathrm{dx}$.doi.org/10.1108/02621710510621286

Hoyt, J. E. (2004). Understanding alumni giving: theory and predictors of donor status. Paper presented at the meeting of the Association of Institutional Research.

Kaplan, A. E. (2007). 2006 Voluntary support of education. New York: Council for Aid to Education.

Lara, C., \& Johnson, D. K. N. (2008). The anatomy of a likely donor: econometric evidence on philanthropy to higher education. Colorado Collage Working Paper No.2008/05, Colorado Collage. Colorado Springs Co.

McAdoo, A. D. (2010). Factors affecting the institutional perception of alumni of the University of Arkansas. Doctoral Dissertation: University of Arkansas.

Mesch, D. J. (2010). Women give 2010: New research about women and giving. The Center on Philanthropy, Indianapolis, IN.

Nunnally, J. (1978). Psychometric Theory (2nd ed.). New York: McGraw-Hill.

Pascarella, E. T., \& Terenzini, P. T. (2005). How college affects students: A third decade of research. San Francisco, CA: Jossey-Bass.

Schervish, P. G. (2005). Major donors, major motives: The people and purposes behind major gifts. New Directions for Philanthropic Fundraising, 2000(47), 59-87. http://dx.doi.org/10.1002/pf.41219971609

Simpson, R., \& Ituma, A. (2009). Transformation and feminization: the masculinity of the MBS and the un-development of men. Journal of Management Development, 48(4), 301-316. http://dx.doi.org/10.1108/02621710910947344

Sun, X. (2005). A multivariate causal model of alumni giving at a Midwest, public university. Unpublished doctoral dissertation, University of Nebraska, Lincoln.

Sun, X., Hoffman, S., \& Grady, M. (2007). A multivariate causal model of alumni giving: Implications for alumni fundraisers. International Journal of Educational Advancement, 7(4), 307-332. http://dx.doi.org/10.1057/palgrave.ijea.2150073

Terry, N., \& Macy, A. (2007). Determinants of alumni giving rates. Journal of Economics and Economics Education Research, 8(3), 3-18. Retrieved from http://www.freepatentsonline.com/article/Journal-Economics-Economic-Education-Research/179817677.ht $\mathrm{ml}$ 
Thomas, J. A. (2005). The relationship between personal and social growth and involvement in college and subsequent alumni giving. Unpublished doctoral dissertation, The University of Memphis, Memphis, TN.

Van Slyke, D. M., \& Brooks, A. C. (2005). Why do people give? New evidence and strategies for nonprofit managers. American Review of Public Administration, 35(3), $199-222$. http://dx.doi.org/10.1177/0275074005275308

\section{Copyrights}

Copyright for this article is retained by the author(s), with first publication rights granted to the journal.

This is an open-access article distributed under the terms and conditions of the Creative Commons Attribution license (http://creativecommons.org/licenses/by/3.0/). 